\title{
LEITURA E MÍDIA
}

\section{LECTURA Y MEDIA}

Hobbs, Renée. Reading the Media: media literacy in high School English. New York:

Teachers College Press, .2009. p. ix +191

O livro trata de assunto de grande interesse pelo impacto da mídia nas pessoas e na sociedade, mas que tem merecido pouca atenção no Brasil e, mesmo no exterior, embora a pesquisa na área não seja recente.

Renée Hobbs leciona na Temple University (Philadelphia), tem longa experiência de ensino na área de comunicação e alfabetização para leitura da mídia, compreensão de TV e outras linguagens. É mestre em arte pela University of Michigan e doutora em educação pela Harvard University.

O livro compreende três partes, conclusão e apêndice. Na parte de agradecimentos a autora fornece também algumas informações sobre o livro como a preocupação de pautar seu trabalho em pesquisa. Narra no livro experiência neste sentido com detalhes que aparecem no apêndice - Delineamento da Pesquisa e Metodologia, investigação qualitativa e quantitativa realizada entre 1998 e 2005.

A primeira parte tem por título Alfabetização em Mídia no Contexto e compreende dois capítulos, sendo o primeiro sobre a leitura da mídia na sala de aula, mostra a importância do aluno aprender o continnum realista - não realista na análise de programas diversos e materiais diferentes para que distingam bem, por exemplo, o que é realidade na TV. Analisa a leitura de textos usando estratégias para distinguir fantasia de realidade, falta de opinião durante as aulas de língua, o que requer saber fazer questões críticas para a análise de qualquer mídia como, por exemplo, Quem está mandando a mensagem e qual o propósito do autor? ou $O$ que foi omitido nesta passagem? (p. 9). Apresenta orientações e informações gerais sobre a pesquisa da qual se originou o livro. O segundo capítulo é uma descrição do contexto da instituição onde a coleta foi realizada com alunos do $11^{\circ}$ ano acadêmico. 
A segunda parte trata especificamente do ensino da alfabetização para a mídia compreendendo três capítulos. No primeiro deles apresenta como trabalhar a leitura de estruturas de narrativa, do fechamento da leitura do ponto de vista do leitor, o que implica no conhecer conceitos ou aspectos que são chave na leitura da mídia: as mensagens são construídas, são usados códigos e convenções para dar formas às mensagens, que tem valores e pontos de vista embutidos, pessoas diferentes interpretam a mesma mensagem de formas diversas, muitas das mensagens da mídia são feitas para ganhar força e poder. $O$ capítulo 4 analisa a ênfase curricular sobre publicidade, persuasão e propaganda. Considera como os professores trabalham isto e que não devem se restringir a análise literária e textual. É recomendável usar outras estratégias para analisar o consumo cultural, ensinar ao aluno o poder do diálogo e dos riscos da manipulação. Seria interessante ter incluído um tópico sobre o trabalho cooperativo entre professores de outras disciplinas. O último capítulo desta parte trata da representação, o uso de estereótipos pela mídia seus problemas e como trabalhar esta questão com os alunos em sala de aula.

A medida da alfabetização em mídia é o cerne da terceira parte do livro e também é constituída por três capítulos. O primeiro deles trata da aprendizagem para ler o mundo lembrando algumas proposições de Freire e Macedo. Usa como exemplo a leitura dos jornais durante a campanha presidencial de 1999 (USA) e o mundo subjacente. Trata também do assistir criticamente aos jornais televisivos apresentando um roteiro para a análise. $O$ sétimo capítulo enfoca a problemática de se medir as habilidades de análise da publicidade, tópico comum nas escolas dos USA, Grã Bretanha, Canadá e Austrália nos vários níveis de ensino. É necessário ensinar defesas cognitivas para que o aluno possa resistir. Isto implica em que conhecer o processo de produção e reconhecer as metas dos produtores que estão subjacentes. Apresentam dados que, por si oferecem um referencial instrumental útil ao ensino e à pesquisa para leitura da mídia criticamente e com compreensão. Atividades neste sentido também levam à melhoria na escrita. Também discute a importância do professor ser um pesquisador e estar relacionando a aprendizagem com a vida.

$\mathrm{Na}$ conclusão a autora enfoca o futuro da alfabetização para a mídia no meio acadêmico destacando os ganhos que isto pode trazer para os alunos em termos de conhecimento, competências e habilidades. Enfatiza a comunidade como um ambiente de aprendizagem e como isto é visto em relação à sala de aula, tendo a Internet um papel importante 
tanto para busca de materiais solicitados como para a pesquisa independente de acordo com temas ou problemas específicos. Há necessidade de proteger o jovem da televisão e da internet que podem trazer prejuízos sociais e intelectuais. O que requer cuidados especiais por parte dos docentes e a atenção dos pesquisadores.

Apresenta também uma relação de fontes úteis para o $11^{\circ}$ grau incluindo livros, vídeos, filmes, outros materiais impressos, programas de rádio e TV, bem como, material dos Websites. As referências incluem clássicos mas também diversos textos mais recentes e de periódicos. É rica e variada. Indice de conteúdo e de autores facilita consulta a tópicos específicos. É texto de grande utilidade para docentes e pesquisadores.

Geraldina Porto Witter-gpwitter@uol.com.br Doutora em Ciências. Livre-docente em Psicologia Escolar. Professora Emérita da UFPa e do UNIPE. Coordenadora geral da Pós-Graduação Stricto Senso da UNICASTELO.

\section{Title}

Reading and media

\section{Titulo}

Lectura y media 